\title{
Question of Identity: Orhan Pamuk's The White Castle
}

\author{
Aarifa Khanum \\ PhD Research Scholar \\ School of Humanities \\ Lovely Professional University \\ Phagwara, Punjab, India \\ aarifakhanum1991@gmail.com
}

\begin{abstract}
Orhan Pamuk is a leading contemporary Turkish writer and winner of the 2006 Nobel Prize for Literature. In his novels he tackles certain universal themes, such as the search for a new identity, the conflict between East and West, the domination of Western culture and its impact on Turkish society, the spread of consumerism, feminism, the search for love and its vanity. Pamuk is influenced by the rich literary tradition of Turkey and at an equivalent time he is affected with the writers like Dostoevsky, Albert Camus, Miller and plenty of others. As a postmodernist author, Orhan pamuk's fiction echoes the priority for the identity of someone. This novel The White Castle is studied for the exploration of the Question of identity like what is real identity of the person. Pamuk himself has faced the perplexity of identity as he is suspect by media of revealing the national sentiment. The protagonist's Hoja and the Venetian traveler are not happy with their gift identity and within the course of their life they assume a replacement identity.
\end{abstract}

Keywords-Identity Question, Orhan Pamuk, Dialectical Relation and Juxtaposition. 


\section{Introduction}

The current Oxford Advanced Learner's Dictionary defines the English dictionary identity as "who or what else" or "characteristics, feelings or belief that set people apart from others." Identity is the characteristics of an individual or group that defines itself. "Identity refers to the whole style of equality within change, which is human life .... The pattern of all these changes continues to me" (Norman, p. 452) .The concept of identity crisis or delusion is elaborated by psychologist Eric Ericsson (1902-1994). Identity issues are within the personality of the individual. Because there is no, it can be discussed from different perspectives. Identity is a very broad term, with different aspects such as people, family, society, nationality, religion, caste, region, language, ethnicity, ideology, gender, etc. can be defined on the basis. Pamuk belongs to Turkey. His work has been translated in additional than sixty three languages worldwide. He has contributed within the Turkish literature by portraying the important state of affairs of Turkey He wrote ten novels; Among them are notable novels:"My name is red" (1998), "Snow" (2002), "Museum of Innocence" (2008) and others. He's a non-conformist writer. Pamuk not only create new ideas but also strive to win them over. He is a postmodern author. His work has the multiple narrators which is the element of postmodern literature. He is deeply privy to his Turkish roots and at identical time he needs to imbibe the trendy values conjointly. Several of his novels are set within the historical past of Turkey. There is intertextuality in his fiction. Several of his characters gift in one novel seem in alternative works conjointly. Pamuk worrieslbothered about the question of identity in his fictions. He time and again ponders over the question of identity like what's the real identity of an individual. What is the role of tradition in shaping the identity? Secondly, he is a supporter, that is, he is a man of entertaining thinking and acting. People with delays make nonlinear jumps in creative and predictable and unpredictable areas. It is rooted in thought and expression. 
Pamuk himself on Identity:

The theme of impersonation used by Pamuk in The White Castle is recurring throughout the rest of its work. He was asked to speak in an interview why did he think that the idea of becoming someone else cropped up so often in his mind and fiction. Pamuk goes back to his childhood to explain his idea of identity. His brother Sevket was eighteen months older than him. They were both a competitor and his brother And his brother was a representative of authority over Pamuk. The older brother was really good at school and smarter than Pamuk. As a result, Pamuk has become a fan of being his brother. The strength and success of his brother impressed him greatly. As a child, Pamuk always tried to act as his older brother, who was stronger and more responsible than Pamuk. For example, in his novel The White Castle, the almost dialectical relationship between the two main characters, the Hoja and the European slave, is based on his actual relationship with his brother.

On Personal identity:

Personal Identity of an individual relates to the self-image or mental model of oneself. It is a psychological relation that outlines the particular identity of the person. An individual has some inborn characteristics and qualities that outline his selfhood and identity. There are bound distinguished qualities of individuals which create them totally different from one alternative. Individual identity is basically framed by a person's own selfhood, behavior and idiosyncrasies, so the person is identified as a unique one from others. A person's identity is thought from different angles like family, caste, religion, region, language then on. The question rises whether or not an individual is pleased with his/her own identity or not, because many time individuals as people deliberately lose their self and pursue for brand new ones as their ideal identity. Typically a personal has aspirations to assume the 
options of people, as a result of he/she is not happy with the present identity of his/her own. Imitation becomes a tool to alter the identity and through it the qualities are non heritable of that another person. The person needs to become some other person by shedding off his/her own identity, because she/he thinks the 'other' to be his model.

The question of identity is discussed mutually of the main themes within the novels of Orhan Pamuk. The novelist explores the themes of the loss of individual identity and quest of a new identity in his novels. In The White Castle, the two look alike persons exchange their identities and complete lives when surfing an extended psychological state. Each the persons lose their individual identities and in search of a brand new one transpose with every others. The problem of personal identity can be studied in detail as it is reflected as a major theme in Pamuk's novel

The White Castle: Identity Exchange

Pamuk's The White Castle belongs to the late 17th century Ottoman Empire. The novelist presents the subject of personal identity in two different ways through the two main characters of the novel. The novelist seeks to dismantle old identities and new ones. The novelist successfully understands the difficulty of exchanging identities between the main protagonist, Hoja (the master) and his narrator, the two main characters. Two main characters; One Turk and the other Venetian, in particular, double their identities with each other and live different lives. The two go through an identity crisis and eventually move on to each other because they are not happy to be 'themselves'. Hoja, the master of Turkey, identifies his Venetian slave to save him from the coming torment and emigrates to Italy, leaving his Turkish identity to the lucky slave who somehow saved him. The master lives a different life in the West, accepting the Western 
way of life. This slave also wants to get rid of his slavery and has the identity of his master and turns him into a royal astrologer in the Ottoman Empire, of course blinding the Turkish people. They both live a perfectly happy life and no one betrays their identity.

To interpret the issue of identity, the novelist brings together two identical people. The novel's anonymous West Venetian narrator is captured and enslaved by Turkish troops in the Mediterranean. In prison, Venetian slaves dream of themselves as free creatures when they are in their hometown of Italy. He almost forgets his self-identity while living as a slave in Istanbul for the rest of his life. The crisis or turmoil of his identity begins when he meets someone who is incredibly similar to him. The narrator himself describes the impressive physical similarities between them.

The resemblance between myself and the man who entered the room was incredible! It was me there... Then I decided he didn't resemble me all that much, he had a beard; and I seemed to have forgotten what my own face looked like. As he sat down facing me, I realized that it had been a year since I last looked in a mirror. (Pamuk, WC, 22)

Ormukh describes physical alikeness and also the physical identities between the two persons. Externally, they two look same however internally they are quite completely different from one another. With the passage of your time, they share their internal identities with one another. The authority hands over the responsibility of the fireworks show at his son's wedding to the person referred to as Hoja, (master) and the slave who is that the verbaliser of the novel. Both, the verbaliser and his master, Hoja with success gift the fireworks show at the marriage ceremony and win the heart of the pasha. Whereas operating along, the verbaliser slave feels his master's interest in him, as he needs to be sort of a 
verbaliser i.e. his master's interest in his identity. With the passage of your time, each the master and slave understand every other's internal characteristics okay. The verbaliser dreams that Hoja exchanges his identity with him and attending to his home in Italy and marrying his bride-to-be and living at his home. Each of them exchanges their information with one another. The pasha believes a lot of within the slave than the master Hoja. No matter Hoja prepares and presents is attributed to the slave and also the credit is given to him. Whenever the pasha appearance at Hoja, he recollects the verbaliser slave and he involves his mind. The sameness of the physical identities of the two persons mixes them into each other's inflicting confusions not just for others however additionally for themselves.

Hoja may be a capricious master who is often excited to try and do one thing for his young ruler and win his heart, however what and the way precisely he doesn't understand. He mostly depends upon his slave, the verbaliser. Sometimes, he seems to be fallen in mental state. He asks his slave “why am I what I am?” (Pamuk, WC, 58). Hoja desires to understand why his identity is what it's. He with impatience wants to understand concerning his identity, maybe due to his slave's similitude with him. Hoja, sometimes loses his religion in himself and seeks facilitate from his slave. He desires to make his identity within the court of the ruler, however does not know how. He tries to indicate his information concerning natural philosophy before the kid Sultan by nonchalantly responsive to his immature queries. In confusion of his own identity, the master plans to share their knowledge of past lives which might facilitate in identity exchange. Hoja ponders over his identity and decides to understand everything concerning his lookalike slave. So both sit face to face and write on their past lives. They are available to understand each detail of their past lives that they share with one another. Later they adopt the manners of every different and exchange their identities. Hoja tortures the slave and also feels pity for him. They write on one another for 
two months and exchange their information. They fight to answer the question, 'why I'm what I am?' Hoja and also the slave dreams their identities obtaining changed, particularly the slave is afraid that sooner or later Hoja would take possession of his identity and hightail it to Italia. The master desires to exchange their information with one another as a result of it's the sole distinction between the two persons. Once they become one in respect of data, they shall be no a lot of completely different persons. Identity crisis becomes outstanding within the plague episode. The plague breaks come in town and Hoja gets a little swelling of red spot below his navel which he thinks to be plague bubo. Before the mirror, each stands facet by facet and feels the putting similitude between them. Hoja scares the slave voice communication that he would take possession of his identity, as a result of once he shaves and also the slave grows his beard, the physical identities would be simply changed. Hoja knows each detail of the narrator's past life, thus he will simply take possession of his identity. The verbaliser gets swamped by the similitude between them once his appearance within the mirror thinking the two is one person. Additionally, master Hoja imitates the movements of the verbaliser that shocks the latter further. Hoja desires to require possession of his slave's spirits. He says: "Now I am like you" (Pamuk, TWC, 83). He additional scares the slave by saying: "I grasp your fear, I even have become you|" (Pamuk, TWC, 83). It is the master who is raring to exchange the identities; however the slave looks reluctant for that deal. The narrator expresses his concern within the following words: "He was attending to take my place, I his, and to accomplish this it might be enough for us to exchange clothes and for him to chop his Beard whereas I left mine to grow" (Pamuk, TWC, 84). Hoja continually desires to become some other person, then selecting the slave's identity. Hoja asks the slave what the latter would do if he takes possession of Hoja's identity, however the slave looks horror-struck even to have confidence exchange of mutual identities. The obsession of the master for exchange of identities is noteworthy when the slave leaves him with concern of his 
suspected plague and runs away from him on associate degree island. He feels that he has lost one thing in absence of the master whereas Hoja feels himself incomplete while not the presence of his lookalike. He gets the slave back and each work on Sultan's order to manage the disastrous plague. Each work along as if they are one. They get conclusion over the plague with the slave's advanced knowledge base of the west. Hoja wins Sultans favors and gets appointed because the Imperial predictor of the Ottoman Empire. For the primary time, the slave feels happy to be a lookalike of Hoja, the master. Their identities of the two persons appear integrated within the crowd celebrating their conclusion over fatal plague. The identities of the two persons utterly mix with one another when they forget their separate selfidentities and become one. The slave lives with the master for an extended time. He bit by bit forgets his past identity as a Venetian and western. When fifteen years of his living with Hoja, his self completely changes into a replacement one. His mind accepts that his past is currently dead and he lives solely within the gift because the double of the master. His past even stops coming into his dreams that symbolizes the loss of his previous identity. He completely forgets his western identity and assumes the Turkish one. In Hoja's company, he exchanges his inner self with him to the massive extent. He has no country, no purpose, and no freedom. Hoja's conclusion looks to be his own, his defeat his own. He gets unexpectedly connected to the master when his success on plague management. The verbaliser sees himself in Hoja's self, thus intimate he becomes to him.

The identities of Hoja and also the verbaliser grow intermingling once the Sultan orders to start out work on Hoja's dream of an unbelievable weapon. Both work along and again once a lot of more exchange their identities. With in the eyes of ruler, both have a same physical look and also the same identity. Their identity such a lot blend into every other's that it is troublesome to take a position what proportion of Hoja is that the slave and the way 
abundant of the slave is Hoja. The ruler invites Hoja and also the slave to the palace to debate on varied problems. Even he cannot distinguish typically which concepts area unit those of Hoja or of the slave. The ruler interrupts one in all them telling that this thought is not his however other's. Sometimes, he asks either of them to become 'himself'. The ruler involves grasp that the identities of each the person's area unit split and they have confusion of identity. The ruler suggests to them to appear into mirror along in order that they will perceive the sameness between them. Hoja loses himself within the work of the unimaginable weapon, he asks the verbaliser to travel to attend the ruler on his place. The ruler calls the slave Hoja as a result of he knows each have same physical personalities and identities. The slave completely possesses the identity of Hoja and wins Sultan's confidence. He enjoys the position of a crucial attendant within the palace. Within the Sultan's eye, the self of the slave is wiser than that of Hoja. At home, Hoja takes place of the slave operating laborious on the invention of the harmful weapon to destroy enemies. Hoja and also the verbaliser utterly exchange their identities, possessing each others. They share their everyday expertise once live along below the same roof. On the expedition to win the Doppio Castle (The White Castle), Hoja and the slave accompany the ruler. On their manner, Hoja makes experiments on the poor villagers to hunt out their transgressions exploitation force and coercing them, maybe attempting to seek out out his own sins out of them. Hoja takes with him his monstrous invention, the unimaginable weapon to use against the Poles and other enemies. Throughout the journey, his machine wastes abundant energy of the hundreds of troopers. This creates a dislike for Hoja among the pashas and soldiers. Hoja is aware of that just in case his machine fails, he could be decapitated by the Sultan. Finally, his weapon badly fails to create state of affairs favorable and Hoja prepares to play a game of fraud along with his slave. He gets rid of all the information concerning the narrator's family, his betrothed, his village and everything about his background. In fact, he desires to organize himself for fraud 
of his precise double, the slave. He is aware of that the troopers area unit talking dangerous not of him however the slave. The rumors are un fold that the slave is that the spy of the enemies, thus his life looks in peril. Hoja plans to flee from the camp, exchanges garments with the slave, and with it they exchange their identities. Hoja becomes the slave and viceversa. Finally, the identities are converse that Pamuk presents in an obscure manner. With good info of the Venetian slave, Hoja escapes from Turkey and flees to urban center, Italy. He lives merrily in urban center with the identity of the verbaliser slave. He becomes a triplecrown author giving lectures in the universities and earns ton of cash. He conjointly marries the slave's betrothed after her husband's death. On the opposite facet, the verbaliser slave occupies the position of Hoja's Imperial predictor. He too gets married to a way younger lady, has four youngsters, makes ton of cash and leaves his position before he is beheaded. Sometimes, the ruler raises queries on his identity. It looks that he is aware of concerning the exchange of their identities. to extend the narrator's anxiety, the ruler typically hints concerning self identity: "Do we all know ourselves? A person should perceive who he is" (Pamuk, WC, 148).

The issue of their identity exchange is not abundant mentioned by individuals, but the ruler deliberately starts rumors that Hoja is not 'himself', but the slave in his kind. The rumors are unfold that their personalities utterly differ and Hoja is that the disguised slave who is that the enemy spy. However the verbaliser manages to create his temperament a lot of like Hoja and does not pay abundant attention to the rumors. He becomes quite unashamed in responsive the questions about his identity. He replies to the queries within the following manner: "Of what importance is it who a person is?" And "The necessary factor is what we've done and can do" (Pamuk, WC, 149). While rebuke the ruler, the verbaliser tries to talk concerning 'Him' who has fled to the west. The ruler is far cleverer who gets rid of all info of 
Italia from the verbaliser. The verbaliser writes a story 'about two men who had exchanged lives' for pleasing the ruler. He mentions the person fled to urban center as 'Him' in his story. The author ends the novel with the two persons living well as old men concerning their seventies. They utterly exchange identities and occupy each other's not solely self however conjointly the families and countries too. In Venice, Hoja's writing is well-received, his books abundant scan, and his lectures at universities listened with nice interest. He becomes quite wealthy by activity all this. Moreover, his slave's former betrothed, swept up within the romanticism of his writings, marries him while not giving a concept to her age or her husband's recent death. They repurchase previous family home of the slave that was shifting and sold, and cool down there. Within the slave's place, along with his identity, Hoja befits and lives merrily ever when. The verbaliser too utterly becomes Hoja and lives merrily in his identity. The author tackles the mental state or confusion of the two lookalike persons and their final exchange of their 'selves'. Naturally their external identities are precisely double and with the time, they share their internal things with one another that mix them along. The loss of identity makes an individual pursue a replacement one as within the case of the Venetian who holds his master's identity and the other way around.

\section{Conclusion}

The question of identity is a major topic in postmodern literature. As a postmodern novelist, Pamuk cleverly handles the issues of identity in his novels. His novels portray the image of identity from different angles. Identity is studied from an individual, collective or national point of view. The identity of the individual is highly important in the collective identity of society and country. Each person is different from others in some aspects that make up their identity. A person has different qualities that distinguish him from others. The novelist presents a man losing his identity and in search of a 
new one. Loss of identity is a deliberate act of the person because the person appears dissatisfied with the current self-identity. In the case of Pamuk's Hoja and White Castle Slave, they exchange their identities to protect themselves from impending disaster. In particular, Hoja Master seems excited for the identity exchange. 


\section{Works Cited}

Identity.(n.d.). $O E D$ Online, Oxford University Press, December 2020, www.oed.com/viewdictionaryentry/Entry/11125. Accessed 22 February 2021.

Norman N. Holland, "Human Identity," Critical Inquiry 4 spring 1978. Print

Orhan Pamuk. Wikipedia, 10 January.2021, https://en.wikipedia.org/wiki/Orhan_Pamuk. Accessed 22 February 2021.

Pamuk, Orhan. The White Castle. Translated by Victoria Holbrook, Carcanet Press Limited, 1990.

--- The Interview Translated by Victoria Holbrook, Carcanet1990. 